\title{
Shakespeare and the silver screen: Reinhardt's Dream, Branagh's Hamlet, and some persistent problems
}

Russell Jackson

\section{(2) OpenEdition \\ Journals}

Electronic version

URL: http://journals.openedition.org/shakespeare/265

DOI: $10.4000 /$ shakespeare.265

ISSN: 2271-6424

Publisher

Société Française Shakespeare

\section{Printed version}

Date of publication: 1 November 1998

Number of pages: 141-148

ISBN: 2-84269-230-6

\section{Electronic reference}

Russell Jackson, «Shakespeare and the silver screen: Reinhardt's Dream, Branagh's Hamlet, and some persistent problems ", Actes des congrès de la Société française Shakespeare [Online], 16 | 1998, Online since 01 November 2007, connection on 06 May 2019. URL : http://journals.openedition.org/

shakespeare/265; DOI : 10.4000/shakespeare.265 


\section{S H A K E S P E A R E \\ \& $\quad$ L E $\quad$ C I N É M A}

Société Française Shakespeare

Actes du Congrès de 1998

米 $*$ *

Textes réunis et présentés par

Patricia DORVAL

publiés sous la direction de

Jean-Marie MAGUIN 
Site web : <http : //alor.univ-montp3.fr/serinf/SFS/> Liste de diffusion : <sfs-1@smrl.univ-montp3.fr >

Tous droits de traduction, de reproduction et d'adaptation réservés pour tous les pays.

(C) 1998. Société Française Shakespeare,

École Normale Supérieure, 45 rue d'Ulm. 75005 Paris.

ISBN 2-84269-230-6 


\section{S HA K E S P E A R E A N D T H E S I L V E R SCREEN : REINHARDT'S DREAM, B R A N A G H S $^{\prime} M L E T$, A N D SOME PER S IS TE N T P R O B LE M S}

A Midsummer Night's Dream, directed by Max Reinhardt and William Dicterle for Warner Brothers, and released in 1935, was a spectacular marriage of Shakespeare with a screen that was literally silver. In the metaphorical sense of the word it epitomised the union of the glamour of movies - costly production values, big stars - with «high» European culture, not just in the shape of William Shakespeare but also of Max Reinhardt, one of the greatest and most versatile theatrical directors of his time. It had all the big-film trappings of advance publicity, with the usual disclosure of behind-the-scenes facts ( More than 600,000 yards of cellophane were used for the ballets; Titania's train required 90,000 yards of gossamer strands alone...»), and the familar suspense as to whether this time Shakespeare would be shown to "work» in the cinema.

The anonymous reviewer in The Times proposed the problem frankly:

No doubt it was too much to expect an adequate performance of a play by Shakespeare in a film, though there does not seem to be any real reason why it should not be attempted, and the result might be extremely exciting... (17 October 1935).

In 1935 the talkies were still young, and Shakespearean sound films a novelty. The critic goes on to observe that Reinhardt's version «has all the 
faults that grandiose stage productions of Shakespeare once committed but have now happily outgrown». Having praised some aspects of the work as cinema, the notice concludes that «[t]here are, however, sufficient reminders of the play to make it difficult to judge Mr Reinhardt's production as an independent film».

This review encapsulates some of the problems that still attach themselves to a greater or lesser extent, to any film based on a play written by Shakespeare : prejudice against the newer medium, comparison with current ideas about putting the plays on stage, and the interference of the original's dramatic form with the process of judging the new work as a film in its own right.

Objections based on the incompatability of the two media are found elsewhere in the British reviews of Reinhardt's film. The Daily Express, under the headline "It Should Never Have been Filmed» admonished the producers : "Shakespeare is not, and never will be, film material. You will never make screen entertainment out of blank verse. It has nothing to do with cinema, which is primarily a visual form" (11 October 1935).

Resistance against American domination of the cinema - a persistent theme still - clearly influenced some other reviewers. This was after all a Warner Brothers' product, and Charles Duff in the New English Weekly announced that «although pork and beans can be successfully canned, it is impossible to can poetry" (24 October 1935). Another review dismissed the film as esimply something which Hollywood could have done quite as revoltingly without Reinhardt» and thought the fairy scenes disastrous (Life and Letters Today, December 1935).

Newspaper reviewers in the 1930s were certainly more inclined than they would be now to dismiss film in itself as a low-status medium, but from the film trade's own perspective the problem was quite the reverse. How would this long (two-and-a-half hour) film go down with audiences? Picture Show assured readers that Reinhardt's Dream was accessible: «I hope that those who read this piecc will not think this film is in any way highbrow. It is a beautiful work of art, but it will appeal to the big public» (19 October 1935). Cinema's headline was "Critics Let Loose Barrage of Superlatives. Remarkable Volume of Praise» (30 October). Film Weekly regarded it as «A marathon attempt to put Shakespeare in the million-dollar class [published estimates of the cost were $£ 300,000]$. Definitely courageous, sometimes impressive, but too often misguided. Some of the performances are irritating, and too many of the sequences become rather boring» ( 9 November). Kinematograph Weekly - a trade paper addressing itself to exhibitors in particular - was more reassuring. Its initial review (12 September) claimed success for the "superlative production» despite the fact that «Shakespeare, hitherto, has not been regarded as commercially kinematographic», and hailed 
«a major event in film development». A subsequent editorial (on 17 October) reinforced the point :

Whether or not the masses are capable of appreciating the full merits of the picture is not, of course, an easy matter for conjecture, but star values should do much to break down the public's coldness towards Shakespeare, and so enable the film to prove a successful box-office, as well as artistic, experiment.

To-Day's Cinema (11 October) printed a summary notice of the film at the head of its fuller review (as an aid to time-pressed professionals) in which the genre was specified («Costume spectacle») and the production values addressed directly. It concluded :

Magnificent staging and mobile camera work fully demonstrate screen's capacity to reproduce imaginings of genius. Quite delightful acting with agreeably little trace of American accent and manner... Serene and distinguished welding of entertainment components suggests vogue for classic films and enormously enlarges scope of screen material.

Other reviews of the film engage more fully with the arguments sketched in here, but I think I have quoted sufficicient to show that some of the perceived problems of Shakespeare on film have been debated since the advent of sound made use of the dialogue possible: the tension between Shakespeare's dramaturgy and that of the screenplay writer; the incompatability of "production values» (especially those of Hollywood) with a poetic text; the difficulty of persuading «the masses» to see Shakespeare in any medium. It is true that in the Dream Reinhardt and Dieterle were tackling a text considered representative of the alleged delicacy of Shakespeare's "poetic» vision and at the same time a reputation (since Hazlitt) as being difficult to stage - but also one which paradoxically lent itself to the techniques of the cinema of fantasy (and even of the Hollywood musicals that Warner Brothers excelled in). Journalists of the 1930s might be more ready than their modern counterparts to claim that something essential and valuable (perhaps even of national significance) had been violated by a film-maker and his paymasters, but otherwise many of the arguments are familiar.

For the present purposes I am leaving aside the issues of «Hollywood» and commercialism, and concentrating on some persistent formal problems in 
the relationship between the media themselves. (I am conscious, of course, that this is an artificial separation). Some of the ways in which the two media diverge can be summarised simply. The cinema offers recorded performance, without a direct influence of spectator on performance ; the film editor and director exercise greater control over the spectator's observation of the action ; the cinema favours sight over speech. Beyond this, one must specify the diverse range of kinds of cinema, and the need for the critic to be receptive and open to as many redefinitions of the medium as possible. (On the other hand, it may be that a great film-maker should have a passionate desire to define the medium on his or her own terms, to be single-minded rather than liberal). It is possible that Shakespeare-on-film is always an exotic specics of film. It uses more words than film usually needs, but perhaps in doing that it identifies itself as a new hybrid.

Unlike adaptations of drama in variations on the naturalistic idiom that we can identify in most modern theatre work (even, say, in Beckett and Pinter) the drama of Shakespeare's time is obstinately stylised in verse dialogue and archaic in prose. Audiences can become acclimatised to these two extremes of Elizabethan stage speech, and it can be argued that the gap to be bridged is narrower than that between opera and cinema, where the physical effort needed to produce the vocal effect defies absorption into a naturalistic idiom. (Although Zeffirelli boldly and successfully takes on both Shakespeare and Verdi in his film of the latter's Otello). The energy required to speak a text written for the stage, the rhetorical patterning that helps a theatre audience to pursue arguments, and the relative lack of reliance on subtext, all put Shakespeare's dialogue in opposition to the prevailing wisdom about screen speech, where eloquence and obvious rhetorical patterning tend to read as signs of deceitfulness, and energy and relish in speaking the lines will seem stagey. On film, more is usually said by the actor's look, the editor's choices and the physical circumstances than by the lines spoken. Film actors are often described as having faces - or even eyes - that the camera loves, and vocal qualities of a more general kind are at a premium rather than specific skill in articulating complex dialogue. But it is not so much the form of the speech, the more or less blank verse, that creates a difficulty, as the amount of it and the work it does for Shakespeare. If we think of great moments in film dialogue - the endings of Casablanca or Some Like It Hot, for example - it is not so much the lines themselves that achieve the effects we acknowledge, as the placing of them, their timing in terms of the film as whole and the editing of the sequence itself. The cinema privileges showing over telling, even when someone is speaking lines that themselves are forceful and aptly turned.

Let me take some of the awkward moments in a film I have worked on and consequently love only just this side idolatry - Branagh's Hamlet - 
that seem to show the distance between Shakespeare's use of spoken word and that of the film. In Act IV, Scene 5 of the play an attendant rushes in to warn of Lacrtes' rebellion in a speech of eleven lines that has two jobs - evoking the threat and urging the king and queen to flee. In the cinema the first half of that task can (indeed ought to) be achieved visually, and we legitimately demand to be shown rather than told such things. Branagh obliges with intercut shots of the approaching mob. At the same time, the length and cloquence of the speech might seem out of place - the words used to make the danger vivid to Claudius are redundant for the spectator. It might be argued further, though, that the particular colour given to the rebellion by this specch («the ocean, overpeering of his list» - Laertes compared to a threat of natural disaster) cannot in itself be illustrated usefully by purely cinematic means, unless one were to include images of the raging sea. A montage might suggest the headlong rush of the invading mob, but cannot give it that specific metaphorical colour without taking too much time or (always a problem) «taking the audience out of the picture» - a feared effect. This is more than a simple matter of balancing words versus pictures : cinema's ability to present metaphor and metonym, to proceed by association and interplay of images, has a formidable rival and counterpart in Shakespeare's language. Eisenstein can show a stone lion seeming to rouse itself, as a metaphor for the anger of the people: Shakespeare can intimate a similar transfer in a few spoken words. The two combined might be an embarrassment of riches, a confusion of signals. The economies of film narration require careful attention to the way in which new characters are introduced : such a complex, eloquent utterance might suggest that more will he (or ought to have been) made of the attendant who speaks it. (For similar reasons one might argue that a «cameo» such as Depardieu's appearance as Reynaldo in Branagh's Hamlet is distracting because it sets up a «rich» character who is never seen again, pushing the film's economy out of balance).

In other cases the film director has less reason to be nervous, because the speaker's importance in the film justifies attention to their way of describing the off-stage action : it is important to see and hear Gertrude describing Ophelia's drowning, or Mistress Quickly's account of Falstaff's death. Even then the film director may feel that the audience needs to see something of the event, either because the character involved in it needs to be established vividly (Falstaff in Olivier's and Branagh's films of Henry $V$ ) or because such a picturesque incident seems to demand illustration on the simple grounds that this is what cinema can do well (the Millais-like Ophelia in Olivier's Hamlet; a brief shot of the drowned woman's head and hair in Branagh's). It may also be the case that the priorities of showing or telling cannot be decided until a late stage in the film-making. In the case of Branagh's Hamlet, 
the screenplay before shooting included, like Olivier's, sequences illustrating Ophelia's account of Hamlet's visit to her room, and also her death. The former was removed after rehearsals convinced the director that it would be more interesting to stay with Ophelia and her father during this sequence; the latter was still in the script at the shooting stage, but it was never filmed. This is not simply a matter of cutting for the sake of screen time (both would run simultaneously with the speeches in question) but of prioritising the spectator's attention.

It is interesting to see what happens when a screenwriter abandons the sequence of the Shakespearean original's narrative in favour of a different set of priorities. Thus, Zcffirelli's Otello adopts Boito and Verdi's strategy of beginning with a vivid storm sequence, and dealing with the «Venetian» first act in retrospect, during a duet between Othello and Desdemona after the riot has been quelled. The librettist and composer make sure that in the context of the storm Iago's villainous intentions are made clear (as they are directly in Shakespeare, Act I) and the film director uses the flashbacks of Othello's wooing and the Senate scene to intimate that the marriage has been consummated in the course of the duet - an opportunity not available to Verdi himself.

Oddly enough, soliloquies are not in themselves as great a problem as one might think. Once one has established a convention (voice over or visible speaking) it can be argued that an audience is soon accustomed to it, and will find it no more problematic than other more directly cinematic conventions - flashbacks for example. The question is really what specific uses will be made of the fact that the actor is speaking to camera : will he or she be, as it were, overheard by us, or will we be addressed directly - even harangued. The latter is the most problematic of choices, for (with the exception of the chorus in Henry $V$ ) a screen personage on screen to show consciousness of the watching audience will break the naturalistic conventions adopted by most Shakespeare films. Who, in such circumstances, can the speaker be addressing? Within the naturalistic convention, directorial tactics for soliloquies range from the camera passing into and through Hamlet's head as Olivier speaks «To be or not to be...» to Kozintsev's King Lear, who is scen speaking his curses to himself as he wanders on the heath, rather than addressing them directly to Regan and Goneril. In his Othello Oliver Parker (himself an actor who had played lago in the theatre) has Branagh's lago address the audience directly. In Much Ado about Nothing Branagh himself holds back direct address from Benedick to the audience until the overhearing scene (allowing the character to be simply pensive, looking to the side of the lens before then). In his Hamlet Kozintsev holds Innokenti Smoktunovski, lips unmoving, in giant close-up as he wanders among the fawning courtiers and ponders the frailty of his mother. Asides, close relatives of soliloquies, 
require similar treatment : Branagh originally considered (and shot) «A little more than kin and less than kind» as a giant close-up on Hamlet's lips, before his whole body was visible to us, but later decided on a closely-microphoned utterance from Hamlet, who is seen from a distance-behind the bleachers on which the courtiers were sitting. (In this case using intimate sound and a distant visual : a mysterious tension to be resolved when we are able to move closer).

It can be argued that the speaker's relationship with the camera in such moments is less important than his or her relationship with the established environment - the milieu of decor and costume on which so great a portion of the film-maker's attention and money have been spent, and which represents the most visible evidence of «production values». Olivier's Hamlet speaks «To be or not to be» in the context of the film's only «real» shots of nature (the sea) and the open air, even though the reverse-angle shots of Hamlet sitting on the precipice are clearly «studio». Similarly, Kozintsev's prince escapes from the oppressive atmosphere of the castle to a prospect of the sea - in the Soviet film-maker's case part of a pattern of open-air shots that begin with film's opening sequence and include the staging of «The Moustrap» outdoors by torchlight, between castle and sea. Smoktunovski, as mentioned above, interiorises Hamlet's first soliloquy. Branagh has Hamlet, left alone in the vast triumphal hall, speak the speech to himself as he walks past the empty bleachers amid the debris of the confetti showered on the royal couple during their exit. Elsewhere, Branagh gives Hamlet his own territory - a book-lincd study - to roam for «My father's spirit in arms» and, more significantly, for «O what a rogue and peasant slave am I» - where the character paces in the room that seems to include symbols of the intellectual and aesthetic life he can all too easily withdraw into. In «To be or not to be» Branagh makes great play with the mirrors that line the hall of the palace, and Hamlet speaks directly to his own reflection and unknowingly to the cavesdroppers. To my prejudiced eye, these seem surprising but effective choices. The oddest strategy of this kind, however, is «How all occasions", which is spoken direct to a retreating camera by a Hamlet who by the end of the speech (and the film's first part) is reduced to a small, shouting figure against a vast panorama of troops moving across a snowy plain in front of jagged mountains. Does this context put Hamlet (so to speak) in his place? Do we regard this speech, delivered at full volume as though it were Henry's exhortation at the walls of Harfleur, as a sign of Hamlet (speaking directly to camera after the first sentence) as ineffectual and bewildered - and if so, is this the vicw of Hamlet himself, or of what we can call «the film»? Whose point of view is this? The music accompanying the shot is certainly more triumphal than ironic, and it rises to a climax as the screen fades to black. Is this a self-consciously - too self-consciously - manufactured climax for the 
interval's sake, or is it a reassertion of the breadth of visual effect the film seeks to put at the script's command? Whatever its effect, it juxtaposes "epic» visual context and intimate private utterance, here transformed into public speech for a public that can only be the viewer, a reversal of the technique used for Hamlet's first words in Branagh's film.

I have dwelt on this sequence in Branagh's Hamlet not because as a collaborator of the director's I have any inside information on it, or in order to praise it, but merely because it seems to me to represent at least two of the difficult points of negotiation in the relationship between Shakespeare's own medium and the cinema. It establishes the milieu of the action, but unlike (say) the staging and setting adopted by various film-makers for Claudius' first speech - public proclamation followed by intimate council chamber in Kozintsev's version, lavish court celebration in Branagh's - the treatment of this soliloquy cannot be identified with such concerns as the characterisation of Elsinore as a court and the new king's regime. On the other hand, it might be seen as relativising Hamlet himself, and as part of the continuing contrast between Fortinbras (seen frequently, and usually silently, in Branagh's film) and the prince of Denmark. In the mode of presenting (and speaking) the text, it seems to embody a contradiction between the intimacy achieved by the stage actor's direct address to his audience and the cinema actor's ability to be overheard. But do these histrionics read as Hamlet's, or the actor's ? Given a particular set of ideas about cinema on the part of the director, is this a point at which those ideas and the original material are in conclict? Is this one of the proofs that (in the words of a reviewer of Reinhardt's Dream) «you will never make screen entertainment out of blank verse»? The fact that Branagh undertook to use all of Shakespeare's words, First Folio conflated with Second Quarto, seems to me to accentuate the problematic relationship of play and cinema in an interesting way. It seems at least to suggest that some of the tensions reflected in those 1935 reviews of the Dream persist to engage or irritate us in filmed Shakespeare.

Russell JACKSON

Shakespeare Institute

Stratford-upon-Avon, Grande-Bretagne 